\title{
Knowledge and attitudes of students in an offshore Caribbean medical school towards HIV/AIDS
}

\author{
Rotimi Orisatoki ${ }^{1,2^{*}}$, Oluwafemi Oguntibeju ${ }^{1}$ \\ From $16^{\text {th }}$ International Symposium on HIV and Emerging Infectious Diseases \\ Marseille, France. 24-26 March 2010
}

\section{Background}

Human Immunodeficiency Virus/Acquired Immunodeficiency Syndrome (HIV/AIDS) is seen is increasingly become one of the most pressing public health dilemma in the Caribbean.

This study is aimed at assessing the level of knowledge, attitudes and misconceptions of the medical students in an Offshore Caribbean Medical School towards HIV/AIDS.

\section{Methods}

Semi-structured questionnaires were used to collate information. Verbal Voluntary consents were obtained fromall the respondents.

\section{Results}

Out of 150 questionnaires distributed, 130 were filled, showing a response rate of $87 \%$. The ages of the respondents ranged from 19-45 years with mean age of 26 . Our finding revealed that the knowledge of HIV/AIDS is high: $97.7 \%$. HIV/AIDS associated beliefs: $22.3 \%$ sees the disease as a punishment for unfaithfulness or immorality. A negative attitude towards HIV patients was seen in $3.8 \%$ of the respondents.

\section{Discussion}

Risky behaviours were identified but the prevalence of such behaviours is low. Religion was identified to play an important role in the conception and misconception about condom usage and possibly transmission of the virus. Behaviour modification course is recommended to

* Correspondence: rotioris@yahoo.com

${ }^{1}$ Spartan Health Sciences University, School of Medicine, Vieux Fort, Saint Lucia be incorporated in the school curriculum to correct misconceptions among medical students.

\section{Author details}

${ }^{1}$ Spartan Health Sciences University, School of Medicine, Vieux Fort, Saint Lucia. ${ }^{2}$ Cape Peninsula University of Technology, Bellville 7535, South Africa.

Published: 11 May 2010

doi:10.1186/1742-4690-7-S1-P138

Cite this article as: Orisatoki and Oguntibeju: Knowledge and attitudes of students in an offshore Caribbean medical school towards HIV/AIDS. Retrovirology 2010 7(Suppl 1):P138.
Submit your next manuscript to BioMed Central and take full advantage of:

- Convenient online submission

- Thorough peer review

- No space constraints or color figure charges

- Immediate publication on acceptance

- Inclusion in PubMed, CAS, Scopus and Google Scholar

- Research which is freely available for redistribution

Submit your manuscript at www.biomedcentral.com/submit 